TILTAI, 2018, 1, 63-75 ISSN 1392-3137 (Print), ISSN 2351-6569 (Online)

\title{
SCHOOL PRINCIPAL'S MANAGEMENT COMPETENCES FOR SUCCESSFUL SCHOOL DEVELOPMENT
}

\author{
Olga Arhipova, Irēna Kokina, Alona Rauckienè-Michaelsson \\ Daugavpils University (Latvia), Klaipeda University (Lithuania)
}

\begin{abstract}
The authors of this article argue that work in the 21 st century is more complex instead of being routine. Solution of education management problems in the Baltic Region is greatly affected by system approach ideas that treat actions as a unified system that consists of mutually related elements with constant interaction of internal and external environment factors. The evolving nature of school environment has placed new demands on educational leaders. Where knowledge of school management, finance, legal issue and state mandates was once the primary focus for the preparation of school leaders, education reform has created an urgent need for a strong emphasis on development of instructional leadership skills to promote good teaching and high level learning. Educational leaders must recognize and assume a shared responsibility not only for students' intellectual and educational development, but also for their personal, social, emotional and physical development. In the article was discovered that school principals need to improve their management competences in personnel management, financial and communication management for successful school leadership.

KEY WORDS: leadership, management, professional development, competences.
\end{abstract}

\begin{abstract}
Anotacija
XXI amžiuje darbas yra sudètingesnis nei ịprasta kasdienè rutina. Sprendžiant švietimo vadybos problemas Baltijos regione svarbus požiūris į vadybą, kaip sistemą, taip pat idejos, traktuojančios vadybinius veiksmus kaip bendrą sistemą, sąveikaujančią su tarpusavyje susijusiais vidaus ir išorès aplinkos veiksnių elementais. Mokyklos aplinka kelia naujus reikalavimus švietimo lyderiams. Nors mokyklų vadovams vadybiniame kontekste didžiulè atsakomybė tenka už finansų valdymą, teisinių valstybės ịgaliojimų ịgyvendinimą, švietimo reforma lemia neatidẻliotiną pedagoginių vadybinių ịgūdžių ugdymo poreikį, siekiant skatinti tinkamo mokymo ir mokymosi procesą. Švietimo lyderiai turi pripažinti ir prisiimti bendrą atsakomybę ne tik dẻl studentų intelektinio, bet ir dèl jų asmeninio, socialinio, emocinio bei fizinio ugdymo rezultatų. Straipsnyje pristatomi rezultatai atskleidžia, kad sėkmingai vadovauti mokyklai siekiantis vadovas privalo ịtvirtinti savo vadybines kompetencijas visais mokyklos vadybos turinio lygmenimis: personalo, finansų ir komunikacijos valdymo.

PAGRINDINIAI ŽODŽIAI: lyderystė, vadyba, profesinis tobulëjimas, kompetencijos.
\end{abstract}

DOI: http://dx.doi.org/10.15181/tbb.v78i1.1757

\section{Introduction}

The turn of the $20^{\text {th }}$ and $21^{\text {st }}$ century "the beginning of the third millennium" is characterized by significant change of values and the development of new perspectives in the global socio-political and economic life. The turn of the century has 
encouraged the people worldwide to make a serious analysis of what has happened, to evaluate more carefully the things going on, and to forecast the future more boldly. The future of mankind cannot be imagined without appropriate education. Jacques Delors, the chairman of the "International Commission on Education for the $21^{\text {st }}$ Century" underlines in the report of the commission: "The commission do not consider education to be a panacea, a magic formula which opens the doors to the world, with the help of which all the ideals will be achieved, but as one of the means at our disposal to advance a deeper and more harmonious development of peoples, thus lessening poverty, banishment, lack of knowledge, oppression and wars." The politicians quite frequently try to avoid considering significant issues of education if it happens at a politically inconvenient time, because, as a rule, the solution of education issues require great financial resources and, for the greatest part, it does not serve their populist aims. That is why education institution principals are of great importance and, as a result of their targeted activities, by influencing the solutions of political processes and education issues, both on the local government and government level, can achieve effective operation and development of education institutions. Practice shows that it is the education institution principals who should be thanked for education development and the rise of its effectiveness. The report of the International Commission also mentions that "school principals are one of the factors, if not the most significant one, who determine the school effectiveness. Sometimes a good school principal, capable of building up an effective team, and who is considered to be competent and ready to support new ideas, substantially improves the school's quality of work" (Delors, 1997).

In order to promote the development of a targeted education policy and effective activities of education institutions, the report of the International Commission focuses on the need for professional education institution principals - "to see to it that the management reins should be in the hands of proficient professionals, who have received special education, among other things, just in the sphere of management" (Delors, 1997).

The aim of this study is to explore school principals' competences for successful school leadership development.

The research method: analysis of scientific literature.

\section{Theoretical overview}

The international practice of educating education institution principals and engaging them in educational process has a common tendency; the political and 
economic changes at the end of the $20^{\text {th }}$ century and the beginning of the $21^{\text {st }}$ century determined the necessity for professional training of education institution principals and deputy principals as well as managers and officials of education boards. In many countries, education institution principals obtain knowledge on issues of educational management in further education programs (the graduates receive a certificate or qualification diploma, which in some countries is equivalent to Master's diploma) or Master's study programs. In several countries it is compulsory for an education institution principal, deputy principals and officials of education boards to obtain specific professional education in education management; however, in other countries it is only preferable. When we talk about a changing environment for the principal the danger is that this may sound too abstract. Briefly, as we see the main shift towards a new principal ship in Europe, it basically means that the principals will move from solely being a manager towards becoming more of an educational leader. The term manager is practically synonymous to administrator, although manager implies 'having decision-making authority'. The emphasis lies on administrative and routine tasks, such as distributing resources, enforcing rules, etc. The concept of leader concentrates on:

- Having a strategic vision about the direction the school should go.

- Having the ability to share the vision in such a way that other in the school are actively pursuing this strategic vision.

High-quality leadership widely acknowledges being one of the most important requirements for successful schools. However, less is known about the forms of leadership development that are most likely to produce effective leadership. Effective leadership is not just a job; it is a complex interaction between a range of personal and professional qualities and experiences. A model of learning that is rooted in personal reflection to enable and enhance understanding and so inform action is at the heart of effective leadership. Leadership in post-modern age is characterized by lifelong learning, learning to learn and just-in-time learning. Report shows the impact of culture, philosophical approaches, hierarchical structures and technology on leadership development.

Within education there is an emerging emphasis on the learning organization. Leadership development is increasingly related to the promotion of collaborative approaches to organizations within which distributed leadership is the dominant mode of professional organization (Hannay \& Ross, 1999). The impact of this on an individual, a group and whole-school leaders is that their development opportunities are increasingly linked to leadership for learning, through transformational philosophies (Crowther, Olson, 1997). 
Harris (Harris, 1999, p. 21) examines the problem of ineffective departments in schools and attributes them, in part, to weak leadership and lack of vision. She claims that "effective leadership essentially involves guiding and supporting staff, particularly those who are having difficulties".

Davies (Davies, 1996) argues that school improvement depends on a different approach to leadership that involves coaching not control, and encouraging the dispersal of leadership and management widely within the organization. Bierema (Bierema, 1997) concludes that "learning organizations have the advantage of turning their learning upon themselves in an effort to improve their process and structure". Hopkins (Hopkins, 2000) argues that school leadership and therefore leadership development needs to be differentiated to take account of the different stages of the school improvement journey.

Effective leadership is the core of every successful organization. Effective leaders collaboratively create a vision and establish a climate for people to reach their highest level of achievement. They mobilize resources and promote collaborative activities among partners to achieve the organization's goals. Effective leaders recognize their own strengths and attract competent people to enhance the organization's capabilities. They cultivate and focus the strengths of colleagues to achieve the shared vision. They welcome change as an opportunity for growth rather than an obstacle to be overcome, and they lead people through the uncertainty of a changing society. Effective leaders seek counsel and advice to learn from the knowledge and experiences of others while they freely offer their expertise to those who seek it. High quality leadership is widely acknowledged to be one of the most important requirements for successful schools (Bush, Jackson, 2002). However, much less is known about what forms of leadership development produce enhanced leadership that leads to school improvement.

All above mentioned reveals that leaders need to supplement and improve their knowledge in management and leadership constantly. They should develop professionally reflecting and reacting on constant changes in politics and economy.

The aim of school leadership professional qualification development is that principals should develop and use a democratic and communicative form of leadership that has its starting point in the national curriculum. Several different concepts are used to describe the leadership development process: leadership training, leadership experience, professional development, management development and management training. 


\section{Career-long learning}

From beyond education, Friedman and Phillips (Friedman \& Phillips, 2002) refer to lifelong learning and provide a powerful justification for 'continuing professional development' (CPD). Just as lifelong learning and the learning society represent a social imperative in a world of rapidly changing knowledge and technology, so CPD must be addressed if professionals are to keep up with these changes. They provide a useful distinction between training, education and development in their discussion of management development:

- The focus of training is the employee's present job.

- The focus of education is the employee's future job.

- The focus of development is the organisation: "Development programmes prepare individuals to move in the new directions that organisational change may require."

A. Thomson, C. Mabey, J. Storey, C. Gray (Thomso, Mabey, Storey, Gray, 2001) draw on a large-scale empirical research with managers and companies beyond education to rank nine leadership development methods on the basis of their perceived effectiveness (See table 1):

Table 1. Leadership development methods on the basis of their perceived effectiveness (According Thomso, Mabey, Storey, Gray, 2001)

\begin{tabular}{|l|l|l|l|l|}
\hline $\begin{array}{l}\text { time off for } \\
\text { courses }\end{array}$ & external courses & on-the-job training & in-house training & job rotation \\
\hline $\begin{array}{l}\text { coaching } \\
\text { managers }\end{array}$ & use of consultants & formal induction & mentoring & \\
\hline
\end{tabular}

Green (Green 2001) stresses the importance of leadership rather than management and refers to Rajan's (Rajan 1996) study of leadership in 500 organisations beyond education. This shows five development modes ranked according to how valuable they were perceived to be (See table 2):

Table 2. Five development modes (According Green, 2001)

\begin{tabular}{|l|l|l|l|l|}
\hline $\begin{array}{l}\text { coaching and } \\
\text { mentoring }\end{array}$ & sideways moves & $\begin{array}{l}\text { challenging assignments that } \\
\text { stretched their capability }\end{array}$ & $\begin{array}{l}\text { networking } \\
\text { with peers }\end{array}$ & $\begin{array}{l}\text { formal } \\
\text { training }\end{array}$ \\
\hline
\end{tabular}

While change was endemic in the profession for the last quarter of the $20^{\text {th }}$ century, the acceleration of change and its pervasiveness for schools means that there 
is now a concern about how school leaders are prepared. The literature suggests that the ubiquity of change, complexity of the role, level of remuneration, status of the profession, legal constraints, and impact on family life are all the reasons why there is dearth of candidates seeking leadership roles in schools. Principals have a central responsibility for raising the quality of teaching and learning for pupils' achievements. This implies setting high expectations, monitoring and evaluating the effectiveness of learning outcomes. A successful learning culture will enable pupils to become effective, enthusiastic, independent learners, committed to lifelong learning (Murphy, Hallinger, 1992).

Effective relationship and communication are important in headship as principal's work with and through others. Effective principals manage themselves and their relationships well. Headship is about building a professional learning community which enables others to achieve. Through performance management and effective continuing professional development practice, the principal supports all staff to achieve high standards. Principals should be committed to their own continuing professional development to equip themselves with the capacity to deal with the complexity of the role and range of leadership skills and actions required (Gronn, 2000).

Principals are in charge of the whole school community. Principals are responsible to a wide range of groups, particularly pupils, parents, careers, governors and local education authorities. They are responsible for ensuring pupils to enjoy and benefit from a high quality education, for promoting collective responsibility within the whole school community and for contributing to the education service more widely. Principals are legally and contractually responsible to the governing body for the school, its environment and its work (Morris, 2005).

Principals provide effective organisation and management of the school and seek ways of improving organisational structures and functions based on rigorous self-evaluation. Principals should ensure the school, the people and the resources within it to be organised and managed to provide an efficient, effective and safe learning environment. These management duties imply the re-examination of the roles and tasks of those adults working in the school to build capacity across the workforce. Principals should build successful institutions through effective collaborations with others (National Standards for principals, DfES/0083/2004: 9).

Three management mechanism component parts, that create, strengthen, develop and unite a school staff (See Figure 1). 


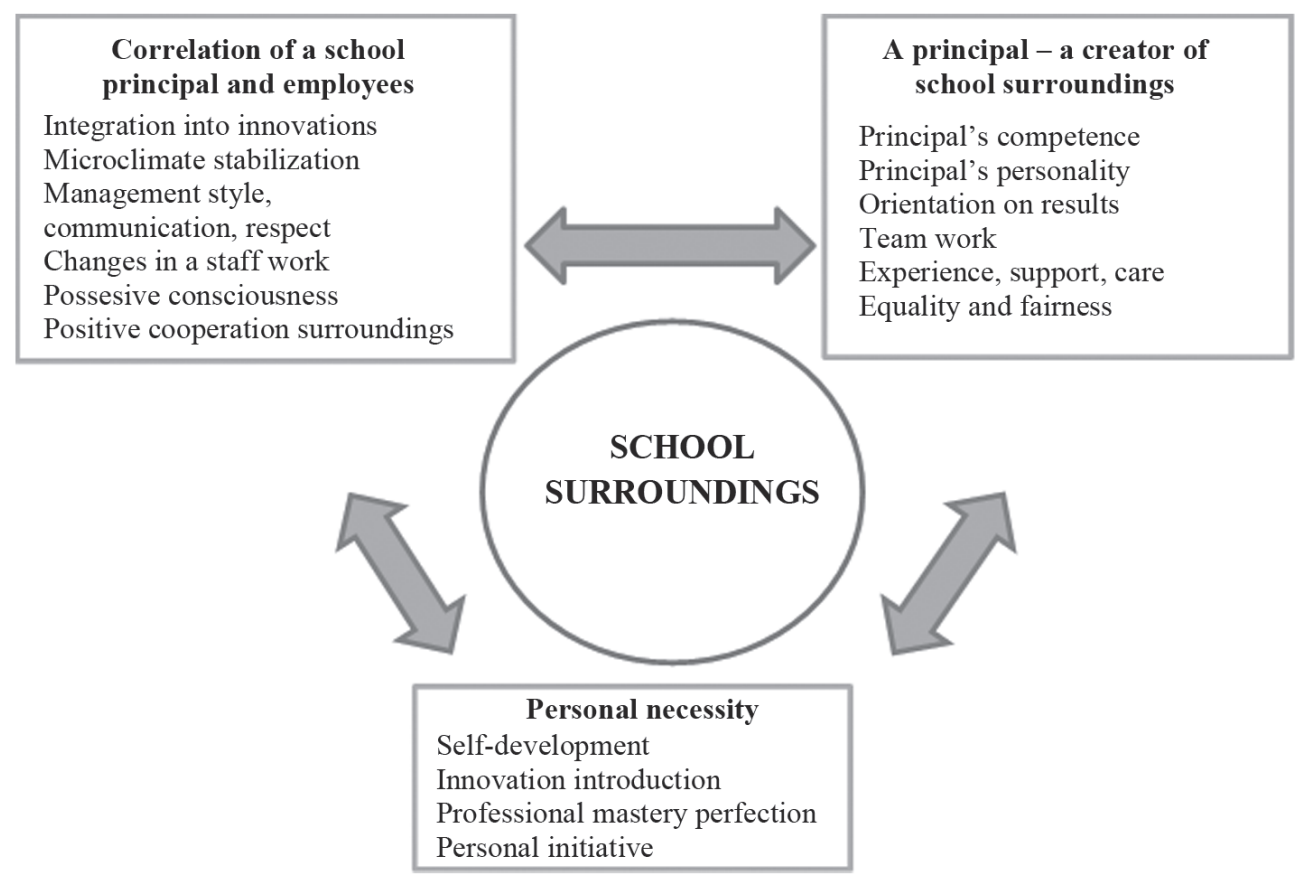

Figure 1. Three management mechanism (Daresh, 2002)

Over the years, three different philosophical orientations have guided the education and professional development of school administrators: traditional / scientific management, craft, and reflective inquiry. The traditional model is characteristic of preparation programs at universities. Principals select this model based on their desire to pursue additional coursework in an area of professional interest, to obtain an advanced degree, to renew or upgrade their administrative license, or a combination of these objectives (Daresh, 2002; Fenwick, Pierce, 2002).

Traditional Model. The traditional model exposes the principal to the research base on management and the behavioral sciences. She/he learns the general principles of administrative behavior and rules that can be followed to ensure organizational effectiveness and efficiency. The participant is often the passive recipient of knowledge and the source of professional knowledge is research generated 
at universities. Learning activities are institutionally defined and generally not tailored to the specific learning needs of the principal or reflective of her/his specific school context.

In more recent years, many school districts, professional associations, and other education agencies have created in - service academies and workshops/ seminars. These academies and workshop/seminar series often have course delivery systems similar to universities, and thus can be characterized as modern versions of the traditional model. Content is changed periodically, usually on the basis of needs assessments administered to potential academy participants. This approach is distinct from other in-service models because of its short-term duration and because it tends to deal with a narrow range of topics, or highly focused topics (Daresh, 2002). Unlike university-based programs, academies and seminars/workshops are more client-driven. Involvement in these types of learning activities normally comes from a principal's personal motivation and desire to learn and grow professionally, not from a need to meet certification or degree requirements (Daresh, 2002).

Craft Model. In the craft model, the principal is trained by other experienced professionals. Here, the principal is the recipient of knowledge from seasoned administrators whom she or he shadows in internships and field experiences. The purpose of shadowing is for the principal-observer to see how another principal interacts with school personnel and the public, deals with problems, and responds to crises. The observer learns another way of handling school concerns. In the craft approach, the source of professional knowledge is the practical wisdom of experienced practitioners and the context for learning is a real school setting (Daresh, 2002; Fenwick, Pierce, 2002).

Reflective Inquiry Approach. In the reflective inquiry approach to professional development, the principal is encouraged to generate knowledge through a process of systematic inquiry. The focus is to create principals who are able to make informed, reflective and self- critical judgments about their professional practice. Here, principals are active participants in their learning, and the source of knowledge is in self-reflection and engagement. The goal is to encourage principals to reflect on their values and beliefs about their roles as school leaders, take risks and explore new skills and concepts, and apply their new knowledge and skills in real school contexts. Networking, mentoring, and reflective reading and writing are key components of this approach (Daresh, 2002; Fenwick, Pierce, 2002). 
The use of networking for professional development of principals is based on the belief that collegial support is needed in order to be an effective school leader. Reference (Owens, 2000) on organizational effectiveness indicates that the presence of norms of mutual support and collegiality results in greater leadership longevity and productivity. Networking involves linking principals for the purpose of sharing concerns and effective practices on an on-going basis. Networks tend to be informal arrangements that emerge when principals seek out colleagues who share similar concerns and potential solutions to problems. However, rather than being periodic social gatherings, true networking is regular engagement in activities that have been deliberately planned by the principals themselves, as a way to encourage collective movement toward enhanced professional performance (Clift, 1992; Neufeld, 1997; Daresh, 2002). Successful professional development takes time. Principals, just like their teachers, benefit from professional development that examines best practices, provides coaching support, encourages risk-taking designed to improve student learning, cultivates team relationships and provides quality time for reflection and renewal. In the end, principals and teachers should leave these experiences with a renewed sense of faith in the transformative power of schools in children's lives. The discussions on the distinction between knowledge, skills and professional attitude showed that current, although substantial and well organized, training programmes for school principals need more real - life cases in relation to modern management techniques. Strategic management module: visionary leadership; identifying the need for systematic change; visionary planning; to build a shared vision in the school management team; understanding the nature of internal and external political systems and environment; development to effective interactive community public relations (Bush, Chew, 1999).

\section{Results}

Study of the education institution principals' personal qualities in order to determine their suitability to management and analysis of their educational activities would ensure a more convincing selection of applicants to the post of the education institution principals and a more successful start of and promotion in the career (See table 3). 
Table 3. The education institution principals' competences (Adey, 2000)

\begin{tabular}{|c|c|}
\hline $\begin{array}{l}\text { Must have competences in: } \\
\text { - jurisprudence - knowledge and understanding } \\
\text { of external laws and regulation, the } \\
\text { development and implementation of internal } \\
\text { rules and regulations, preparation of projects } \\
\text { and agreements; } \\
\text { - communication - development of interrelations } \\
\text { with the subordinates, the learners and their } \\
\text { parents, representatives of the community, } \\
\text { service providers and suppliers of goods, } \\
\text { partners, clients, as well as knowledge and } \\
\text { skills of information technologies and foreign } \\
\text { languages; } \\
\text { - management - work with the personnel, } \\
\text { organization and management of projects, } \\
\text { management of various competitions, } \\
\text { management of quality and changes; } \\
\text { - education - education of values, interactive } \\
\text { methods, novelties in theory and practice, } \\
\text { knowledge of and skills in social and special } \\
\text { pedagogy, skills in research in education; } \\
\text { - economics - composition of the budget and its } \\
\text { realization, attraction of sponsors, marketing } \\
\text { of education products, ensuring assistance in } \\
\text { the development of the learners' economic } \\
\text { competences }\end{array}$ & $\begin{array}{l}\text { Must know about: } \\
\text { - significance of interpersonal relationships, } \\
\text { adult learning and models of continuing } \\
\text { professional development; } \\
\text { - } \text { strategies to promote individual and team } \\
\text { development; } \\
\text { - } \text { building and sustaining a learning } \\
\text { community; } \\
\text { - } \text { relationship between managing } \\
\text { performance, CPD and sustained school } \\
\text { improvement; } \\
\text { - impact of change on institutions and } \\
\text { individuals; } \\
\text { - models of organisations and the principals } \\
\text { of organisational development; } \\
\text { - principals and models of self-evaluation; } \\
\text { - principals and strategies of school } \\
\text { improvement; } \\
\text { - project management for planning and } \\
\text { implementing change; } \\
\text { - policy creation, through consultation and } \\
\text { review; } \\
\text { - informed decision making; } \\
\text { - strategic financial planning, budgetary } \\
\text { - performance management; } \\
\text { - personnel, governance, security and } \\
\text { access issues relating to the diverse use of } \\
\text { - legal issues relating to managing a school } \\
\text { including equal opportunities, 'race' } \\
\text { relations, disability, human rights and } \\
\text { employment legislation }\end{array}$ \\
\hline
\end{tabular}


is committed to:

- effective working relationships;

- shared leadership;

- effective team working;

- CPD for self and all others within the school;

- distributed leadership and management;

- equitable management of staff and resources;

- sustaining of personal motivation and that of all staff;

- developing of a safe, secure and healthy school environment;

- collaborating with others in order to strengthen the school's capacity and contribute to the development of capacity in other schools is able to:

- foster an open, fair, equitable culture and manage conflict;

-develop, empower and sustain individuals and teams;

-collaborate and network with others within and beyond the school;

•challenge, influence and motivate others to attain high goals;

-give and receive effective feedback and act to improve personal performance;

-accept support from others including

colleagues within the local education authority (LEA);

-establish and sustain appropriate structures and systems;

-manage the school effectively on a day-today basis;

- delegate management tasks and monitor their implementation;

-prioritise, plan and organise himself/herself and others;

-make professional, managerial and

organisational decisions based on informed judgements;

-think creatively to anticipate and solve problems

\section{Conclusions}

1. Principals training must be based on a holistic view of the school in which the organization of the programme, its relationship with the local community, and knowledge of school conditions together constitute important elements. The training emphasise a capacity for reflection, for critically processing information and solving problems. Important starting points for the development of competence are the principal's own experience of various types of work in school. Ideas, concepts and theoretical models from relevant areas of research and development will provide increasing knowledge and understanding of both one's own experience as well as other's contribution to school. 
2. The training must be based on a view of leadership in school that will promote a working climate inspired by openness, reflection and learning. The purpose of the training is to deepen principals' knowledge and increase their understanding of the national school system, the national goals of the school and the role of the school in the society and the local community. The training will allow principals to deepen their knowledge of the role of leadership in a school system managed by objectives and results, as well as develop their ability to plan, implement, evaluate and develop school activities. The training also aims at development of the capacity of the principals to analyse and draw conclusions from the outcomes of such activities and be able to share their views. Principals will also develop their ability to co-operate both inside and outside the school in addition to representing the school in the community.

\section{References}

Adey, K. (2000). Professional development priorities: the views of middle managers in secondary schools. Educational Management and Administration, Vol. 28 (4), p. 419-431.

Bierema, L. (1997). Learning Organisations: Evaluating Learning and Results. Paper for the 27th SCUTREA Conference.

Bush, T., Chew, J. (1999). Developing human capital: training and mentoring for principals. Compare, Vol. 29 (1), p. $41-52$.

Bush, T., Jackson, D. (2002). A preparation for school leadership: international perspectives, Educational Management and Administration, Vol. 30 (4), p. 417-429.

Crowther, F., Olsen, P. (1997). Teachers as leaders - an exploratory framework. International Journal of Educational Management, Vol. 11 (1), p. 6-13.

Daresh, J. (2002). Research base on mentoring for educational leaders: what do we know? Journal of Educational Administration, Vol. 33 (5), p. 7-16.

Daresh, J., Fenwick \& Pierce (2002). Professional Development for Principals. ERIC Clearinghouse on Teacher Education Washington DC: Corwin Press. ED 477731

Friedman, A., Phillips, M. (2002). The role of mentoring in the CPD programmes of professional associations, International Journal of Lifelong Learning, Vol. 21 (3), p. 269.

Davies, B. (1996). Re-engineering school leadership. International Journal of Educational Management, Vol. 10 (2), p. 11-16.

Delors, J. (1997). Learning Together Throughout Our Lives. Discussion kit on the Report to UNESCO of the International Commission on Education for the 21st Century, p. 142.

Green, H. (2001). Ten Questions for School Leaders. Nottingham, NCSL. Available at www.ncsl.org.uk/ knowledgepool/foundations

Gronn, P. (2000). Distributed properties: a new architecture for leadership. Educational Management and Administration, Vol. 28 (3), p. 317-338.

Hannay, L., Ross, J. (2001). Department heads as middle managers? Questioning the black box. School Leadership and Management, Vol. 19 (3), p. 345-358.

Harris, A. (1999). Effective Subject Leadership: A handbook of staff development activities. London: David Fulton. 
Hopkins, D., Harris, A., Jackson, D. (1997). Understanding the school's capacity for development. School Leadership and Management, Vol. 17 (3), p. 401-411.

Hopkins, D. (2000). Beyond School Improvement - Valuing Educational Reform. London: Falmer Press.

Morris, M. (2005). The first-time manager: the first steps to a brilliant management career. 3rd edition. London; Sterling: Kogan Page Limited.

Murphy, J., Hallinger, P. (1992). The principalship in an era of transformation. Journal of Educational Administration, Vol. 30 (3), p. 77-88.

Rajan, A. (1996). Leading People. Tunbridge Wells, CREATE.

Thomson, A., Mabey, C., Storey \& Gray (2001). Changing Patterns of Management development. Oxford: Blackwell. 
